\title{
İslam Düşüncesinde Muhalefet
}

\section{Abdulnasır SüT*}

\section{The Opposition in the Islamic Thought}

Citation/(C: Süt, Abdulnasır, (2018). The Opposition in the Islamic Thought, Milel ve Nihal, 15 (2), 60-83.

Abstract: If the opposition is made for human rights and justice it is essential or indispensable and if it is made for injustice, cruelty, corruption and mischief it is wrong according to the Qur'an and Sunnah which are the main sources of Islam. Considering the practices of Muslims, it is possible to make an assessment in context of the intellectual and political opposition. However, political opposition has not been seen on the institutional and social level and has always faced a crisis of legitimacy. In the political history of Islam, it was seen that all kinds of opposition was supposed to be "other" by the sovereign political power and it was sought to be condemned by defaming it as illegitimate. A form of political organization, which is shaped on the axis of imamate, sultanate and caliphate, will disclose very different practices than the forms of organization in democratic administrations. Undoubtedly, the principal means of the establishment of human rights and justice is the state mechanism. This mechanism is required to be properly designed and structured, and a powerful opposition whose legislative framework has been identified is required to monitor the practices of the government.

Keywords: opposition in Islam, the opposition practice of Muslims, intellectual opposition, political opposition.

* Doç. Dr., Bingöl Üniversitesi, İlahiyat Fakültesi, Kelam Anabilim Dalı [nasr_12@hotmail.com]. 
Atıf/@: Süt, Abdulnasır, (2018). İslam Düşüncesinde Muhalefet, Milel ve Nihal, 15 (2), 60-83.

Öz: İslam'ın temel kaynakları olan Kur'an ve Sünnet esas alındığında muhalefetin hak ve adalet için yapılması gerekli veya zorunlu; haksızlık, zulüm, fitne ve fesat için yapılması yanlış olmaktadır. Müslümanların tarihsel pratikleri dikkate alındığında ise fikri ve siyasi muhalefet merkezinde bir değerlendirme yapmak mümkündür. Ancak siyasal muhalefet, kurumsal ve toplumsal düzeyde yaşanmamış ve hep bir meşruiyet sorunu yaşamıştır. İslam siyasi tarihinde muhalefetin her türlüsünün egemen siyasi güç tarafından "öteki" olarak kabul edildiği ve meşru olmadığını gösterme cihetine gidilerek mahkûm edilmeye çalışıldığı görülmektedir. İmamet, saltanat ve hilafet ekseninde şekillenen bir siyasal örgütlenme biçimi, demokratik yönetimlerdeki örgütlenme biçimlerinden çok farklı pratikler ortaya koyacaktır. Hakkın ve adaletin ikamesinin en büyük aracı da şüphesiz devlet mekanizmasıdır. Bu mekanizmanın doğru bir şekilde belirlenip yapılandırılması, yapılan uygulamaların denetlenmesi adına yasal çerçevesi belirlenmiş bir muhalefet gereklidir.

Anahtar Kelimeler: İslam'da muhalefet, Müslümanların muhalefet pratiği, fikri muhalefet, siyasi muhalefet.

\section{Giriş}

Bu çalışmada İslam'ın muhalefet olgusuna nasıl yaklaştığı temel sorusundan hareketle Müslüman düşünce ve siyasi geleneğinde muhalefetin teorik ve pratik düzeyde neye tekabül ettiği konu edinilecektir. Muhalefetin ne'liği ve muhalefet yapma biçimleri siyasetin önemli konularındandır. Muhalefet yapmanın gereği, değeri ve sınırlarına ilişkin düşünce ve siyaset sahasında çokça fikir ileri sürülmüştür. Muhalefet, bir tür fikir zenginliği, insanların düşünce ve pratik hayatları üzerine bir denetim aracı olarak görüldüğü gibi fikri, siyasi ve toplumsal birlikteliği zedeleyici bir eylem olarak da telakki edilmiştir. Muhalif düşünce ve eylemin değeri, sübjektif bir mahiyet arz etmesine rağmen, ona ilişkin hüküm zaman ve şartlara bağlı olmanın yanında taraflara ve amaçlara göre verilir. Kime, ne için, ne zaman ve nerede muhalefet edildiği, muhalefetin değerini ortaya koymaktadır.

"Muhalefet" ve "ihtilaf" kelimeleri farklı anlam içeriklerine sahip olsalar da aynı kökten, h-l-f (half) kavramından türetilmiş birer mastardır. Râgıp el-İsfahânî ihtilaf ve muhalefeti “tutum veya sözde 
birinin gittiği yoldan başka bir yol tutma" manasında ${ }^{1}$ kullanırken Seyyid Şerîf Cürcânî ihtilaf kelimesinin kök kavramı olan hilafı, "iki muarız grup arasında hakkın ortaya çıkması veya batılın geçersiz kılınması için meydana gelen tartışma" şeklinde değerlendirmektedir. '̇ Isfahânî, muhalefet kelimesini zıddı, münazaayı ve mücadeleyi kapsayacak şekilde geniş bir anlam yelpazesinde kullanmaktadır. Ayrılık, anlaşmazlık, aykırılık ve uyumsuzluk manalarında ${ }^{3}$ olan ihtilaf dini, siyasi, içtimai ve hukuki alanlarda görüş ayrılığı manasında kullanılmıştır. Ancak zamanla İslam düşüncesinde ihtilaf kavramına olumsuz anlam içerikleri pek yüklenilmezken muhalefete daha fazla olumsuz anlamlar yüklenmiştir. Hilaf ve ihtilaf, âlimlerin içtihadi görüş ayrılıkları ile mezhebi farklılıklar özelinde ele alınmıştır. Fikri görüş farklılıkları, ulema tarafından hoş görüyle karşılanmış, bazen zaruret, rahmet ve servet olduğunu ifade etmişlerdir. ${ }^{4}$

Muhalefetle ilgili bir diğer kavram olan el-mu'ârada; "karşılık verme, müzakere, itiraz etme, karşı görüş belirtme ve reddetme" anlamlarını içermektedir. ${ }^{5}$ Bu kavram, Arapçada son dönem siyaset teorilerinde muhalefet bağlamında kullanılmıştır. ${ }^{6}$ Yine bağy ve tefrika kavramlarının da muhalefet kavramıyla ilişkisi vardır. Bağy kavramı, dini-ahlaki bir kavram olmasının yanında hukuki ve siyasi bir kavram olarak da kullanılmıştır. Sözlük anlamı "haktan ayrıl-

1 Râgip el-İsfahânî, el-Müfredatu elfazi'l-Kur'an, thk.: Safvan Adnan Davudi (D1meşk: Daru'l-Kalem, 2009), 294. Râgıp el-İsfahânî hilaf, halef, hilafet, halife, muhalefet, muhalif ve muhtelif gibi kelimeleri de half kavramından türediğine dikkatimiz çekmektedir.

2 Seyyid Şerîf Cürcânî, et- Ta'rifat, thk.: Nasruddin Tunusi, (Kahire: 2007), 169.

3 Türk Dil Kurumu Sözlüğü, "İhtilaf”, md.

4 Yusuf el-Kardavî, İhtilâflar Karşısında İslamî Tavır, Çev.: Osman Arpaçukuru, (İstanbul, İlke Yayıncılık, 2. Baskı, 1996), 77-110. Kardavî, kitabının birinci bölümünde İslam'ın esas itibariyle ayrılı̆̆ı hoş görmediğini vurgulamakla beraber İslam tarihinde fikri ve ahlaki saiklerle övgü ve yergi konusu olabilecek birçok ihtilafın meydana geldiğine dikkatimizi çekmektedir.

5 Geniş bilgi için bk. İbn Manzur, Lisanü'l-Arab, (Beyrut: Daru'l-İhya Turasi'l-Arab, 3. Bask1, trs), IX/138-150.

6 Nevin Abdulhâlık Mustafa, İslam Düşüncesinde Muhalefet, Çev.: Vecdi Akyüz, (İstanbul: İz Yayıncılık, 2001), 55. Nevin Abdulhâlık, bu eserinde, mu'ârada kavramını, günümüz muhalefeti için değil, İslam siyasi tarihindeki muhalefet bağlamında kullanmıştır. O, bu eserinde İslam siyasi düşüncesinde muhalefetin teorik dayanaklarını, tarihsel yansımalarını ve düşünce ekollerinin muhalif tutumlarına ilişkin değerlendirmelerde bulunmuştur. 
mak ve haddi aşmak" manasında olan bağy; adil (meşru) devlet başkanına karşı isyan etme anlamındadır.7 İslam tarihinde yönetime karşı yapılan isyanlar bağilik olarak kabul edilmiştir. Fırka kavramı ile aynı kökten gelen tefrika ise muhalefetle ilişkili olarak kullanılmış ve ona olumsuz anlamlar yüklenmiştir. Kur'an'da ve Sünnette tefrika, ümmetin toplumsal ve siyasal birlik ve bütünlügü bölücü manada kullanıldığı için olumsuz anlamlar içermiştir. ${ }^{8}$ İslam tarihinde fikri, itikadi ve siyasi egemenliği elinde bulunduranlar muhalefete, egemen düşünce ve uygulamaya karşı taşıdığı itirazdan dolayı olumsuz tavır almışlardır.

Muhalefet kavramını, bugünkü demokratik ve parlamenter sistemlerde kazandığı anlam çerçevesinde kullanmadık. Köken itibariyle Arapça olan muhalefet kavramını, Müslümanların fikri ve siyasi düşüncesinde farklı görüş ayrılıkları ve eylemleri kapsayacak bir genişlikte değerlendirdik. Muhalefet kavramı, fikri (hilaf, ihtilaf, cedel, münâzara, münazaa, mu'ârada) ve siyasi (mücadele, tefrika, bağy) karşı koyuşları da kapsayacak genişliktedir. Nazari ya da fiili karşı koyuşların hepsi birer muhalif tutumdur. Oysa muhalefet kavramı bugün düşünceden ziyade siyasal alanda parlamenter sistem içindeki iktidarda olmayan siyasi kuruluşları ifade eden bir terime dönüşmüştür. Muhalefet demokratik toplumlarda ve çok partili yönetim sistemlerinde yaygın ve meşru bir olgu olarak telakki edilmektedir. Teokratik, monarşik, totaliter yönetimlerde veya çok partili olmayan parlamenter sistemlerde ise yasal çerçeve içerisinde var olan kurumsal muhalefetten söz edilemez. Ancak buna rağmen her toplumda ve yönetimde, egemenlerin olduğu tüm sosyo-kültürel ve siyasal zeminlerde egemen düşünce ve politikaya karşı farklı seviyede düşünce ve tavır geliştirenler var olagelmiştir. Bireyin içinde yaşadığ 1 siyasal, sosyal ve kültürel çevrede egemen görüşlere ve uygulamalara karşı farklı bir görüş veya tavır ortaya koyması bir muhalefettir.

\section{İnsan ve Muhalefet}

Muhalefet, insanın doğal yapısındaki farklılıktan, insanın biyolojik, psiko-sosyal, düşünsel ve duygusal açıdan çok karmaşık bir yapıya sahip olmasından kaynaklanan bir olgudur. İnsanın bu özelliklerinin belirlenmesinde kalıtsal ve sosyo-kültürel etmenlerin çok farklı

7 İbn Manzur, Lisanü'l-Arab, I/455-458; Ali Şafak, "Bağy", DİA, İstanbul, 1991, IV/451.

8 Tuncay Başoğlu, “Tefrika”, DİA, İstanbul, 2011, XL/279. 
olması, insanların farklı duygu, inanç, düşünce ve eylemler ortaya koymasına sebep olmaktadır. Hatta insan kendisine baktığında bile bu ihtilafı, karmaşıklığı ve zaman zaman zıtlığı görebilir. İnsanın biyolojik olarak çok karmaşık bir varlık oluşu, onu duygusal ve düşünsel olarak da çok karmaşık kılmaktadır. İnsanoğlu her zaman aynı düşünce ve inanca sahip olmadığı gibi aynı eylemlere ve tepkilere de sahip olmayacaktır. Bazen aynı hadiseler karşısında bile çok farklı tepkiler vermekte ve farklı tavirlar ortaya koyabilmektedir. Kişinin düşünce, inanç ve davranışlarını belirleyen unsurların çokluğu ve karmaşıklığı bu farklılığın nedenidir. İnsanoğlunun değer yargıları ve kaygıları, kişinin farklı tavır ve tutum almalarında önemli bir belirleyiciliğe sahiptir. Bir insanın duygu ve davranışlarında her zaman bir homojenlik olmadığı kabul edildiğinde, doğal olarak bireylerden teşekkül eden toplumda da bir homojenlikten bahsedilmeyecektir. Toplumsal grupların var olduğu her tarihsel süreçte muhalefet de doğal olarak var olacaktır. Muhalefet, düşünce, inanç, sosyal ilişkinin var olduğu bütün sosyal gruplarda, yöneten ile yönetilen ilişkisinin var olduğu bütün sosyal ve siyasal süreçlerde var olacaktır. Ancak muhalefet yapmanın nedenleri ve saikleri aynı olmayacaktır. Ahlaki bir varlık olarak insan değerlerini yaygınlaştırma ve koruma çabasındadır. Sosyal ve politik bir varlık olarak insanoğlu, yaşadığ1 toplumda statü kazanma, politik olarak egemen olma arzusundadır. Refah düzeyini arttırmak, sosyal statüsünü güçlendirmek ve ekonomik olarak daha güçlü olmak için gayret verenler de olacaktır. İktidar olmak, kamu gücünü eline geçirmek, dünya nimetlerine erişmek, hayatta idealini gerçekleştirmek, değerlerini korumak ve amacına ulaşmak gibi farklı saiklerle insanoğlu çeşitli ihtilaflar yaşamaktadır. İnsanoğlu psiko-sosyal yapısı gereği toplumda nüfuz sahibi olmak istemektedir. Bu istek kişiyi toplumda egemen olan söylem, fikir, eylem ve değer anlayışları veya yönetim erkinin uygulamaları karşısında bir pozisyon almaya götürecektir. Dile getirilen söyleme, düşünce veya dayatılan uygulamalara karşı sözlü ya da fiili karşı koyuşlar birer muhalefet tarzıdır. Bu karşı koyuşlar insani değerlere, ahlaki zemine ve toplumsal bir kabule dayanırsa ortaya konulan itiraz ve muhalefet meşru bir nitelik kazandığı gibi bu eylemi ortaya koyanları da önemli tarihi şahsiyetler yapar.

Muhalefet yapma imkânını insanoğluna veren en temel şey iradedir. İrade; kişinin farklı tercihlerde bulunma imkânıdır. Cürcânî iradeyi; canlıyı (kişiyi) kendisinden fiillerin şöyle değil de böyle 
doğmasını sağlayacak bir duruma getiren nitelik ${ }^{9}$ şeklinde tanımlamaktadır. İnsanın irade sahibi özgür bir varlık oluşu, ona farklı fikir ve inançları benimseme imkânı verdiği gibi onlar için farklı eylemde bulunma imkânı da vermektedir. Aynı konularda farklı tercihlerde bulunma, farklı inanç ve ilkeleri benimseme, doğal olarak farklı görüşleri ve yaşam pratiklerini doğurmaktadır. İnsanların inanç, fikir ve yaşam pratiklerini beğenme, benimseme durumları olabileceği gibi beğenmemeleri hatta itirazları olabilir. Fikir ve pratikler övgü alabileceği gibi yergi de alabilirler. Ortaya konulan itirazlar, karşı çıkışlar ve mücadele muhalefeti doğurmaktadır.

İnsanların akıl seviyelerinin, bilgi ve tecrübelerinin farklı oluşu kişinin düşünce ve duygu dünyasını etkilemekte, doğru-yanlış ile iyi-kötü hakkında değerlendirmelerini farklılaştırmaktadır. İnsanoğlunun farklı ilke ve değerleri kişinin inanç, fikir ve eyleme ilişkin görüşlerini şekillendirmektedir. Ahlaki bir varlık olan insan değerlerini yaşama ve yaşatmaya hatta onları hâkim kılmaya çalışacaktır. İnsanların sahip oldukları inançlar, bilgiler ve değerlerinin farklılığı, tüm bu alanlarda birbirleriyle mücadeleyi kaçınılmaz kılmaktadır. Kur'an-1 Kerim, insanların inanç ve görüş noktasında ihtilaf etmelerini normal karşılamakta, bunun beşeri bir durum olduğuna işaret etmektedir: "Rabbin dileseydi elbette bütün insanları tek bir ümmet yapardı. Hâlbuki yine de ihtilaf edip duracaklardır." ${ }^{10}$

\section{İslam ve Muhalefet}

İslam dininin muhalefete imkân tanıyan dayanaklarına geçmeden önce şu hususa dikkat çekmekte yarar vardır: İslam dini, insanl1ğın/Müslümanların doğru inanç ve eylemlere (iman-salih amel) sahip olmalarını, hak ve adalet üzere hareket etmelerini ve bunu başarabilmek için ayrıllğa değil, birleşmeleri gerektiğine vurgu yapmaktadır. Ancak dinin temel gayesi bu olmakla birlikte insanoğlu, sahip olduğu akıl seviyeleri, tercihleri, iradesini etkileyen motivasyonları ve eylemlerini belirleyen imkânlarına bağlı olarak farklı düşünceleri/inançları ve eylemleri benimsemekte ve buna uygun bir yaşam pratiği ortaya koymaktadır. İnsanların epistemoloji anlayış-

\footnotetext{
Cürcânî, et-Ta'rifat, 34.

10 Hud 118.
} 
ları ve yöntemleri ihtilafı kaçınılmaz kılmaktadır. Bu durumu farkında olan Müslüman düşünürler İslam'da ihtilafın mahiyeti ve usulüne ilişkin birçok eser kaleme almışlardır. ${ }^{11}$

İslam düşüncesinde insan teklife muhatap olan, emaneti yüklenen, ${ }^{12}$ yeryüzünü inşa ve imarla sorumlu olan ${ }^{13}$ ve yeryüzüne halife kılınan ${ }^{14}$ bir varlıktır. İnsanoğlunun bu yükümlülükleri üstlenmesi kendi bireysel tercihine bırakılmıştır. Allah, insana kendisine iman etme ve tanıma gücü verdiği gibi isyan etme gücü de vermiştir. ${ }^{15}$ İyi işlerin yaygınlaşması ve ikamesi ile kötülüğün engellenmesi ve ortadan kaldırılması İslam'da teklifin temel konularındandır. Bu sorumluluğun gereği olarak Müslüman zulme rıza göstermeyecek, zalim yöneticiye karşı hakkı söyleyecek, hak ve adaletin tesisi ve temini için gayret gösterecektir. Peygamber efendimize atfedilen bir hadiste gücünüz varsa elinizle, yoksa dilinizle, o da mümkün değilse kalbinizle buğz ederek tavır alınması gerektiğine vurgu yapılmıştır. ${ }^{16}$ Ayrıca, Hz. Peygamber, zalim sultanın önünde hak sözü söylemeyi en büyük cihat olarak kabul etmiştir. ${ }^{17}$

İslam'da muhalefet yapmanın imkânı ve gerekliliği, dini ve ahlaki bir ilke olan emr-i bi'l-ma'ruf ve nehy-i ani'l-münker ilkesine dayandırılmaktadır. Bu ilke hem Kur'an-1 Kerim hem de Sünnet üzerinden temellendirilmektedir. İslam, Müslümanlara yeryüzünü 1slah etme, adaletin kaim olduğu bir hayat oluşturma sorumluluğu yüklemiştir. "İçinizden iyiliği emreden ve kötülükten nehy eden bir topluluk bulunsun"18 ayeti, bu sorumluğu Müslüman bireye ve topluma yüklemekte, hatta bu işin örgütlü bir şekilde yapılmasını talep etmektedir. Yine "Erkek ve kadın bütün iman edenler birbirlerinin dostudurlar. Birbirlerini iyi ve doğru olanın (maruf) yapılmasına

11 İslam düşüncesinde özellikle Usulü Fıkıhta fukahanın ihtilaflarını konu edinen ve ihtilafların nedenleri üzerinde duran müstakil eserler vardır. Bu konuda ayrıntılı bilgi için bk. İzmirli İsmail Hakkı, İlm-i Hilaf (İstanbul: Dar Saadet, 1330); İbn Seyyid el-Batlayusi, el-Insaf, thk.: Muhammed Rıdvan Daye, (Suriye: Daru'1Fikr, 2003); Cabir Alevâni, İslâm'da İhtilâf Usûlü, Terc.: Abdulhalim Ural, (İstanbul: Risale, 1991).

12 Ahzab, 72.

13 Hud, 61.

14 Bakara, 30.

15 Kehf, 29.

16 Ebu Davud, "Melâhim”, 17, (VI/395).

17 Ebu Davud, "Melâhim", 17, (VI/400).

18 Ali İmran,104. 
özendirir, kötü ve zararlı olandan (münker) sakındırırlar"19 ayeti de, iyiliklerin çoğaltılması ve kötülüklerin ortadan kaldırılması sorumluluğunu Müslüman topluma yüklemektedir.

Müslümanlardan hayra çağırma, iyiliği emretme ve kötülüğü men etme sorumluluğu yapacak bir grubun bulunması daha çok dini tebliğ kapsamında ele alınmaktadır. Oysa yukarıda bahsedilen ayetlerin kapsamı toplumsal işleyişin tüm kademelerine; siyasi, ekonomik, hukuki, sosyal, dini vb. tüm alanlara şamildir. Çünkü tüm bu alanlardaki işlerde iyi, doğru, güzel işler gerçekleştiği gibi kötü, zulüm, yanlış ve çirkin diyebileceğimiz işler de vuku bulmaktadır. İşte İslam toplumsal düzenin hak üzere varlığını devam ettirebilmesi adına Müslüman topluma hak ve adalete uygun siyasi, ekonomik, hukuki bir sistem tesis etme sorumluluğu yüklemektedir.

İslam siyasi düşüncesinde muhalefet olgusunun temellendirilebileceği önemli dayanaklarından birisi "şura/meşveret" ilkesidir. Kur'an-1 Kerim'de, "işleri aralarında danışma iledir" 20 ayeti, farklı görüşlerin bir arada tartışılmaya ve değerlendirilmeye açılmasına imkân vermektedir. Demokrasi ile ilişkilendirilen ve demokrasinin bir çeşidi olarak da değerlendirilen şura, işlerin danışma ve istişare ile yapılmasını öngörmektedir. Bu anlayışta temsiliyet açısından bir belirlenim ve adalet olmasa da, temsilcilerin danışma ile iş yapmaları, farklı görüşlere açık olmayı gerekli kılmaktadır. İslam, temsiliyet biçimi ve yönetim şeklinden ziyade idarecilerin hak ve adalet üzerine uygulamalarda bulunmalarını esas almaktadır. Doğru kararların alınabilmesi için de temsilcilerin aralarında danışma/istişare ile iş yapmalarının önemine yapmaktadır. İstişarede muhalif görüşlerin varlığı bazen önemli politikaların yeniden çizilmesine veya uygulanan politikanın denetimine vesile olur.

Muhalefete imkân tanıyan ilke ve dayanaklar İslam'da vardır. İslam'da akıllı ve reşit olan kişi teklife muhatap olmakta ve bazı sorumluluklarla mükellef tutulmaktadır. Teklife muhatap olan insanın Yaratıcının emir ve hükümlerine bağlı olarak inşa ettiği değerleri ve sorumluluklarını yerine getirme yükümlülüğü bulunmaktadır. Bu sorumlulukların sadece Yaratıcıya ibadet sahasıyla sınırlı olmadığı yukarıda ifade edilmişti. Sorumluluğun bir gereği

19 Tevbe, 71.

20 Şura, 38. 
olarak doğru bulmadığı eylemlere karşı tavır alacak, yanlış olan işlerin düzeltilmesi, adaletin ikame edilmesi ve hak ile hukukun işlediği sosyal bir düzenin oluşturulması için gayret gösterecektir. Yeryüzünde zulüm, fesat ve kötülüğün engellenmesi, adaletin toplumda kaim olması ve dünyadaki maddi imkânların fakir ve yoksul insanlara ulaştırılması gibi toplumsal, hukuki, idari ve ekonomiyle ilişkili birçok alanda sorumluluklar yüklemektedir. Birçok ayette bu minvalde emir ve uyarılar bulunmakta, değere dayalı bir yaşam pratiğini bizden talep etmektedir. Peki değere dayalı bir yaşam pratiğinin olmaması, haksıllık ve zulmün var olması durumunda ne yapılmalıdır. İşte burada İslam, muhalefeti zorunlu kılmaktadır. Bu zorunluluk, yeryüzünde iyiliğin, adaletin egemen kılınması ve kötülüğün azaltılması adına Müslümana yüklenen sorumluluktan kaynaklanmaktadır. Müslüman ulema (aydın) ve ümera (siyasetçi) bu sorumluluğun gereği olarak bir yönetimsel sistem tesis etmeli ve bunun doğru işlediğini takip edecek denetim mekanizması oluşturmalıdır. Derin ve karmaşık bir ilişki ağına dayanan toplumsal uygulamalara ve siyasi erkin politikalarına bireysel olarak muhalefet etmek vicdani bir sorumluluktan öteye geçmez. Muhalefeti örgütlü ve meşru düzeyde yapmanın imkânı bulunmalıdır. Muhalefet, var olan uygulamaya, politikaya, düşünceye alternatif oluşturabilmeli ve sunduğu alternatifleri uygulayabilme imkânına sahip olmalıdır. Demokratik toplumlarda ve partili meclislerde muhalefet yasal bir zeminde yapıldığından özgüven telkin eder. Ancak yasal bir zemine dayanmayan muhalefet, kişiyi tedirgin etmekte ve zor duruma düşürebilmektedir. Otoriter yöneticilerin tahammül ve merhametine kalan bir muhalefetin günümüz dünyasında bir faydası yoktur. Tarihsel tecrübeye baktığımızda siyasi sistemler örgütlü muhalefete imkân tanımamışlardır. Ne saltanat, ne imamet, ne hilafet ne de başka bir yönetim örgütlü muhalefeti meşru bir zeminde yapmasına imkân tanımıştır. Monarşik veya oligarşik bir yapıyla tevarüs eden yönetimler, muhalifleri fitneci, asi, baği, nankör olarak nitelemiş hatta küfürle itham etmiş, baskı ve güçle ortadan kaldırmak istemiştir.

Şüphesiz İslam'a göre muhalefetin değeri, yapılan muhalefetin dinin makâsıdıyla ne ölçüde uyumlu olduğuyla doğrudan ilişkili bir keyfiyet arz etmektedir. İslam dini açısından ele alındığında muhalefetin meşruluğu; muhalefetin çıkış nedeni ve hedeflerinden hareketle belirlenir. Muhalefet edilen konu, dinin gerçekleştirmek istediği hedeflere matuf olarak ferdi çıkarlardan uzak ve toplumsal 
faydaya dönük olmalıdır. Fikir ve inanç düzeyindeki fikri cereyanlar ile toplumsal ve siyasal uygulamalar, kişinin din ve dünya görüşü bağlamında bir karşılık bulacaktır. Din açısından muhalefetin kaynağı nass ise, bir başka ifade ile eğer muhalif naslardan hareketle muhalif bir söylem ve eylem gerçekleştiriyorsa bu değerlidir. Başka bir ifadeyle kişi, dini değerleri, dinin emir ve hükümlerini esas alarak muhalif bir duruş sergiliyorsa, bu dinin olumlu gördüğü bir durumdur. Eğer muhalefet Kur'an-1 Kerim'de de belirtildiği üzere peygamberlerin getirmiş olduğu hakikatlere, inanç ilkelerine ve hükümlere karşı bir itiraz, red ve tartışma şeklinde ise İslam böyle bir muhalefeti kabul etmez ve benimsemez. ${ }^{21}$

Muhalefetin hükmü konusunda üç temel yaklaşımdan bahsedilebilir. Özetle; şayet muhalefet Allah'ın hadlerinin çiğnenmesine, zulme ve adaletsizliğe, ahlaki davranış bozukluğuna veya din hükümlerinden birine aykırılığa karşılık yapılıyorsa burada hüküm vacip sayılır. Allah'ın emirlerinden birini inkâr, sahih ve sabit olan sünnetle gelen hükümlere itiraz anlamında ise, burada hükmü haramdır. Çünkü şer'i işler ihtilaf konusu olamazlar. Zira müminler hakkında farz olan Allah'ın ve peygamberinin hükmüne tam teslimiyet göstermektir. ${ }^{22}$ Şayet muhalefetin kaynağı, asabiyet, bireysel çekişme, ekonomik fayda, toplumda statü kazanma, itibar ve şan elde etme amaçlı ise böyle bir muhalefet din açısından içeriksel bir övgü hak etmemektedir. Bu iki alanın dışında kalan muhalefet kısmı için mübahlık söz konusudur. Burada bireyin statüsü, eğilimleri, kaygıları ve tercihleri etkili olmaktadır.

\section{Müslümanlar ve Muhalefet}

Hz. Peygamber'in vefatından sonra Müslüman toplumda baş gösteren ihtilafı Şehristânî, birisi "imamet" diğeri "usûl" de olmak üzere iki kısımda ele almaktadır. ${ }^{23}$ Usûlde muhalefet, esas itibariyle ekoller tarafından caiz görülmese de tarihsel vakıa, bu alanda da birçok ihtilafın meydana geldiğini göstermektedir. Her ekol kendi usûlleri/asıl ilkeleri üzerinde ittifakı gerekli, muhalefeti ise yanlış saymıştır. Her ekolün usul ilkelerinin farklılığı ve ilkeler üzerinde

$21 \quad$ Bk. Bakara, 213, 253; Yunus, 93; Hud, 110, 118; Nahl, 39, 64, 92, 124.

22 Mustafa, İslam Düşüncesinde Muhalefet, 124.

23 Ebu'l-Feth M.b. Ebi Bekr Ahmed eş- Şehristani, el-Milel ve'n-nihal. I-II, thk.: Emir Ali Mehna, Ali Hasan Faur, (Beyrut: Daru'l-Marife, 2001), 40. 
yapılan tartışmalar, bu alanda da ihtilafın kaçınılmaz olduğunu ortaya koymaktadır. ${ }^{24}$ Erken dönem İslam siyaset tarihinde imamette yaşanan krizler ve ayrışmalar yeni teşekkül eden Müslüman toplumda ihtilafları derinleştirmiş, farklı siyaset teorilerin üretilmesine, üretilen teorilerin teolojik temellendirmelerine neden olmuştur. $\mathrm{Bu}$ ihtilaf türü, İslam'da ilk kanın akıtılmasına sebep olduğundan, Müslüman toplumun birlikteliğini bozmuş, farklı fikri, siyasi ve itikadi oluşumların ortaya çımasına neden olmuştur. İlk dört halife döneminden itibaren asabiyete dayalı bir iktidar belirleniminin varlığı, İslam toplumunun bir gerçekliğidir. Hz. Osman'ın şehit edilmesi, Hz. Ali'nin iktidarı döneminde yaşanan Cemel ve Sıffin hadiseleri buna bağlı olarak ortaya çıkan Hariciler, ilk dönem İslam toplumunun kendi içerisinde ciddi ayrışmayı ve fiili müdahaleyi gerektiren ilk sorunlar olmuştur.

Düşünce ve siyaset geleneğimizde genel olarak muhalefet kavramına pozitif bir anlam yüklenmeyişin çeşitli nedenleri vardır. İslam dininin, teslimiyet ve itaat üzerine varlık kazandığ düşüncesinden hareketle muhalefet tefrika, fitne, isyan ve küfür ile ilişkilendirilmiş ve ümmetin birliğini hedef alan bir kavram olarak kullanılmıştır. Bunun bir kısım nedenlerine kısaca işaret edebiliriz.

Egemen fikri ve itikadi söylem, farklı görüşleri bid'at/zeyğ olarak telakki etmesi. Bu yaklaşım dini ve fikri düzeyde, muhalifinin görüşünü değersizleştirmek için kullanılan bir yaklaşımdır.

İktidarların meşruiyetlerini teolojik olarak temellendirme çabaları. Bu çabalar iktidara karşı muhalefeti meşru zeminden çıkarmıştır. İktidar, egemenliğini teolojik argümanlarla desteklediğinde, muhalefet fitne olmuş olmaktadır.

Yönetim sistemlerinin çok sesliliğe ve muhalefete imkân tanımaması. İslam tarihinde yönetim biçimleri olan hilafet, imamet ve saltanat; biat, tayin ve nesebe dayandığından, toplumsal tabandan tavana doğru bir iktidar arayışına imkân vermemektedir. İktidara yönelik talepler, isyana dönüşmüş ve şiddetle bastırılmıştır.

İslam tarihinde devlet başkanı olan kişinin, genellikle ölünceye kadar o makamda kalması. Böyle bir tarihsel gerçeklik, iktidarın el

24 Sinan Öge, "Usûlu'd-Dinde İhtilafın Hükmü ve Eleştirisi”, Ekev Dergisi, 11/33, Güz 2007, ss. 107-120. 
değiştirmesi ihtimalini meşru zeminde ortadan kaldırdığından muhalefet arayışlarını zayıflatmıştır.

Görüş ve yorumların zamanla dini bir karakter kazanması. Çünkü dini bir hükme ve uygulamaya muhalefet doğru değildir. Dolayısıyla bu meyandaki muhalefet, toplum nazarında kişilerin dini ve sosyal itibarını giderici ya da zayıflatıcı bir argüman olarak kullanılmıştır.

İslam tarihinde imamet, hilafet ve saltanata dayanan bir yönetim biçimi, söz konusu denetime imkân tanıyacak bir kodlanmaya ve yönetimsel esnekliğe sahip olmamıştır. Din, mezhep ve soya dayandırılan bu yönetim şekilleri, toplumdan gelen talepleri, farklı sesleri ve itirazları çoğu zaman dikkate almadan yönetimlerini sürdürmüşlerdir. İktidar gücüne talip olan veya doğru yönetilemediklerini savunanlar, bu tür yönetimlerde asi, baği, nankör isimleriyle tanımlanmaları uzak bir ihtimal değildir. İyi bir yönetim, toplumsal taleplere kulak vermeli, eleştirileri ciddiye almalı, gelen muhalif görüşleri bir denetim aracı olarak görmelidir. Bu anlayış bireysel ve toplumsal yükümlülükler doğurmakta ve toplumda düşünsel ve eylemsel bir tavır almayı zorunlu kılmaktadır. Sorumluluğun hissedildiği her alanda tavsiye, telkin, eleştiri, itiraz gibi sözlü ya da protesto, isyan gibi fiili karşı koyuşlar yaşanabilir. Bunlar muhalefetin değişik segmentleri olarak değerlendirilebilir.

\section{Fikri Muhalefet}

Müslümanların muhalefet yapma imkânı, düşünce ve siyaset tarihinde aynı olmamıştır. Müslümanların tarihsel pratikleri esas alındığında muhalefetin fikir ve siyaset odağında geliştiği söylenebilir. Fikri muhalefet, teorik düzeyde kaldığı sürece bir zenginlik olarak telakki edilirken, uygulama da asilik/bağilik, fasıklık, inkârcılık, bidatçllık gibi negatif anlam içerikleriyle ön planda olan kavramlarla ilişkilendirilmiştir.

İslam dininin temel referansı olan Kur'an-1 Kerim, insanın inanç kalıplarını sorgulamadan kabul etmesini kınamıştır. ${ }^{25}$ Hakikati öğrenme adına yapılan sorgulama, doğal olarak fikri muhalefete imkân verir. Hz. Peygamber'e atfedilen, “ümmetimin ihtilafı rahmettir" sözü, ihtilafın tarihi süreç içerisinde vuku bulacağını ve bunun zararlı bir şey değil rahmet olarak telakki edilmesini telkin

25 Bakara, 170. 
etmektedir. Bu zaviyeden bakınca İslam, bireyin farklı görüş ve kanaatte olmasını meşru bir hak olarak telakki etmiştir. Hatta Allah, doğru kabul etmediği ve kâfir olarak nitelediği fikir ve inançta bulunan insanlara karşı şiddeti değil, bazen yumuşak sözle uyarılmaSın1, ${ }^{26}$ bazen de kendi inancına terkedilmesini ${ }^{27}$ salık vermektedir.

İslam düşüncesinde ihtilafın meşruiyeti inanç konuları (usulü'd-din) ve fıkhi hükümler (für'u'd-din) üzerinden değerlendirilmeye alınmıştır. ${ }^{28}$ Allah'ın varlığı ve birliği konusunda ihtilaf caiz görülmezken Allah'ın sıfatları, kaza ve kader gibi konulardaki aykırı yaklaşımlar bid'at olarak değerlendirilmiştir. Diğer konularda ihtilaf ise caiz görülmüştür. ${ }^{29}$

Fikri muhalefet bazen yeni bilimsel ve düşünsel çabaların nedeni, bazen de fitne ve ayrılığın tohumu olarak değerlendirilmiştir. Düşünce tarihimizde, fikri muhalefete genel anlamda tolerans tanındığı söylenebilir. Felsefi, kelami ve tasavvufi çevrelerin varlık ve bilgi telakkilerine ilişkin düşüncelerinin geniş bir yelpaze oluşturması, bu görüşümüzü desteklemektedir. Düşünürlerimizin bu konulara ilişkin tartışma imkânına sahip olmaları, fikirlerini özgürce savunabilmeleri, telifat desteği bulmaları ile miras bıraktıkları farklı ve zengin fikri yekûn, fikri muhalefeti kabullendiklerinin bir göstergesidir. İslam tarihinin genel işleyişinin aksine bazı düşünürlere (filozof, kelamcı, hadisçi vb.) yönelik baskı ve dişlama, bu genel atmosferin olmadiğı anlamına gelmez.

İslam'da fikri/itikadi ihtilaflar, hicri birinci asrın ortalarından beri varlığını devam ettirmektedir. Bu ihtilafların harici ve dâhili nedenleri vardır. Dinin temel referanslarından hareketle farklı anlamalar yaşandığı gibi siyasi hadiseleri dini zeminde değerlendirmeden kaynaklanan farklı fikirler gelişmiştir. Siyasi tartışmaları ile anlaşmazlıkların sebep olduğu fiili durumlar (Hz. Osman'ın şehadeti, Cemel ve Sıffin savaşları) Müslüman toplumun siyasi birlikteliğini bozduğu gibi fikri ve itikadi ayrışmalarının temel nedeni olmuştur. Toplumdaki fikir ve itikat anlayışı da yaşanan hadiselerde tarafların pozisyonlarına bağlı olarak şekillenmiştir. Yukarıda anılan hadiselerde Müslümanların birbirlerini öldürmele-

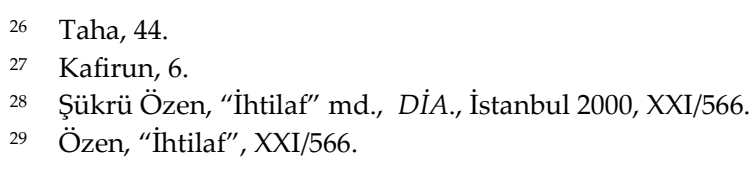


rine bağlı olarak büyük günah işleyen kişinin iman durumu ele alınmış, amelin imandan bir parça olup olmadığı meselesi ortaya çıkmıştır. Emeviler döneminde yöneticilerin yaşadıkları meşruiyet krizi hem siyasi hem de fikri ihtilafı derinleştirmiştir. Emevi yöneticilerin iktidarlarını kadere izafe etmelerinin önemli bir nedeni siyasi meşruiyet arayışıdır. Siyasi hadiselerin doğurduğu bir diğer fikri (itikadi) ihtilaf efdal-mefdul meselesidir. Kimin iktidara daha ehil veya kimin hakkı olduğu tartışmaları, o dönemin siyasi hadiselerinden bağımsız değildir. Büyük günah işleyen kişinin imani/dini ve hukuki durumu, kader, fiillerini gerçekleştirmede insanın hürriyeti, ilahi adalet, Allah'ın zat ve sıfatları gibi meseleler ilk dönem İslami fırkaların düşüncelerinin farklılıklarını belirginleştiren konulardır. ${ }^{30}$

Erken dönem İslam toplumunda yukarıda anılan konulara bağlı olarak gelişen kelami problemler, kelamcılar ile hadisçiler arasında itikadi meselelere ilişkin birçok tartışmayı beraberinde getirmiştir. ${ }^{31}$ İslam düşüncesinin teşekkül dönemleri kabul edilen hicri ilk dört asırda ilmi meclislerde yaşanan fikri tartışmalar, yapılan cedel ve münâzaralar fikri muhalefetin Müslüman toplumda benimsendiğinin bir diğer göstergesidir. Özellikle o dönemde hâkim olan cedel (münâzara), ilim çevreleri nezdinde önem verilen bir anlayış, yöntem olarak karşımıza çıkmaktadır. Hatta bazı Emevi ve Abbasi halifeleri, âlimleri bir araya toplayarak bir konu etrafında tartışmalarını sağlamışlardır.

İslam düşüncesinde fikri ihtilafın çokça yaşanması, aynı konularda birçok görüşün serdedilmesi fikirsel zenginliğin göstergesidir Kur'an-1 Kerim ve Sünnet'in sarih bir şekilde ortaya koyduğu hüküm ve uygulamalar hariç diğerleri içtihadi ve nazari çabaların semeresidir. Böyle telakki edildiğinde düşünce bir esneklik kazanmakta, farklı görüş ve yorumlar bir zenginlik kabul edilmekte ve aykırı görüşlere olan tahammül genişlemektedir. İslam düşünce tarihinde bu esneklik, tolerans ve hoşgörü başta fıkıh olmak üzere kelam ve diğer İslami disiplinler için de söz konusudur. Müslüman düşünürlerin birbirlerine yazdıkları reddiyeler, kelami, fıkhi ve felsefi ekollerin birbirlerine getirdikleri tenkit ve nakzlar fikri mücadelenin sadece sözlü tartışma ve cedelden ibaret olmadığını

\footnotetext{
30 M. Sait Yazıcıoğlu, İslam Düşüncesinin Tarihsel Gelişimi, (Ankara: 2001), 43.

31 Bk. Talat Koçyiğit, Hadisçiler ile Kelamcılar Arasındaki Münakaşalar, (Ankara: AÜİF. Yay., 1969).
} 
göstermektedir. Müslüman düşünürler bazen bir ekolü bazen de bir âlimi merkeze alarak reddiyeler yazmışlardır. Bu tür telifatlar, İslam düşünce geleneğinde çok önemli bir yer tutmaktadır. ${ }^{32}$

İslam düşünce geleneğinde içtihadın önemli bir yeri vardır. Müçtehidin içtihatta bulunurken isabet etmesi durumunda iki, hata yapması durumunda bile bir sevap alacağ ${ }^{33}$ inancı, âlimleri cesaretle akli çıkarımlarda bulunmaya, özgürce görüş ve fikirlerini serdetmeye teşviktir. Fıkıh imamlarının bu konudaki yaklaşımları takdire şayandır. İmam Malik, meşhur kitabı el-Muvatta'nın kanun kitabı haline getirilme teşebbüsüne karşı çıkmış, içtihad mekanizmasının toplumsal ihtiyaçlara binaen özgürce yapılmasının bir rahmet olduğuna vurgu yapmıştır. ${ }^{34}$

İslam mezhepler tarihine bakıldığında ekollerin veya âlimlerin karşı düşünce ve inanç biçimlerine duydukları hoşgörü ve tahammül açıça görülmektedir. Söz gelimi İmam Eş'arî'nin (ö.324) Makālâtü'l-İslâmiyyîn ve İhtilâfü'l-Muṣallîn isimli eserin isminde bile bu tolerans ve karşı düşünceye olan tahammül açıkça görülmektedir. Eserde İslam dinini anlama farklılığından dolayı oluşan mezheplerin tümünün görüşleri sunulmaktadır. Bunların içerisinde aşırı Rafızi gruplar dâhil Şia, Hariciler ve Mutezile'nin tüm grupları yer almakta ve bunların görüşleri mümkün oldukça objektif bir şekilde sunulmaktadır. İslami Görüşler ve Namaz Kılanların İhtilafı şeklinde tercüme edebileceğimiz kitap ismi, tüm bu ekolleri namaz kılanlar ve görüşlerini de İslami olarak tanımlamaktadır. ${ }^{35}$ Dinin anlaşılması adına ortaya çıkan farklı görüşleri İslam şemsiyesi altına alarak ifade etmek, muhalif görüşlere verilen önemi ve toleransı göstermesi açısından önemlidir. Farklı görüşlerin bulunması ve düşüncenin dinamik bir şekilde varlığını sürdürmesi için muhalefet bir

32 Bu konuda ayrıntılı bilgi için bk. Niyazi Kahveci, "Şîa ve Mu'tezile'nin Reddiye Literatürü Üzerine Çalışma", Dini Araştırmalar Dergisi, c. 8, S. 23, ss. 69-91; Abdulnasır Süt, Basra ve Mutezile, (Ankara: İlahiyat Yayınları, 2016), s. 65-65. Mutezili düşünürlerden Ebü'l-Hüzeyl, Şia, Kaderiyye, Cebriye ve Mürcie'ye; Nazzâm Şia, Cebriye ve Mürcie'ye; Bişr b. Mutemir Havâric ve Cebriye'ye yönelik eleştirileri ve reddiyelerde bulunmuşlardır. Mutezili iken daha sonra Mutezile'den ayrılan Dirâr b. Amr, Hafs el-Ferd, İbnü'r-Râvendî ve Ebü'l-Hasan el-Eş‘arî gibi düşünürler de itizal düşüncesine tenkitler yöneltilmiştir.

33 Buhari, "I'tisam”, 21, VI/2676.

34 Kardavî, İhtilaflar Karşısında İslamî Tavır, 105-106.

35 Bk. Ebu'l- Hasan el-Eş'arî, Makalâtü'l- İslâmiyyîn ve ihtilâfu'l-musallîn. Nşr. Helmut Ritter, (Wiesbaden: 1980). 
gerekliliktir. Farklı görüşlere olan toleransı gösteren yaklaşımlar geleneğimizde genelde şu şekilde ifade edilmiştir: Bu konuda şu görüş (rey), kavl (söz), içtihatlar da var manasında çok sayıda ifade biçimleri vardır. Bunların yanlışlığı ve geçersizliği (butlan) izaha çalışılır ama mutlak hakikat iddiası ile bu temellendirilmez.

\section{Siyasi Muhalefet}

Hz. Muhammed'in içinde yaşadığı toplumsal yap1, toplumun siyasi, sosyal ve ekonomik tavır alımlarında önemli bir belirleyiciliğe sahiptir. Arap toplumunun siyasal ve sosyal işleyişi, genellikle kabile yapısına istinaden varlığını sürdürmekteydi. Bu durum Arap dünyası için peygamber efendimiz ve daha sonraki süreçte hatta bugün bile neredeyse aynıdır. Siyasal örgütlenmeler ve muhalefetler de bu toplumsal yapıya bağlı olarak vücut bulmuştur. İslam dininin temel gayesi Arap toplumunun kabile mantığı anlayışını ve gerçekliğini İslam kardeşliğine ve ümmetine dönüştürmekti. İslam tarihinde bir bütün olarak bakıldığında kabile olgusu yerine din olgusunu, nesep yerine takvayı ölçü alması gereken Müslümanların siyaset arenasında bunu başardıklarını söylemek mümkün değildir. İslam, Müslüman toplumun ihtiyaç duyduğu politikaların belirlenmesini ve uygulanmasını, tarihsel ve toplumsal gerçekliği dikkate alarak belirlemeyi toplumun aydın ve yönetici kesimine yüklemektedir. Kur'an-1 Kerim herhangi bir yönetim şekli önermediği gibi Hz. Peygamber de önermemiştir. İslam dininde asli iki otorite merciinin yönetime ilişkin herhangi bir belirlenimleri din olarak telakki edilecekti. Dini merciilerin doğrudan belirlenimde bulunmaması, ulema (filozof, siyaset bilimci, aydın) ve ümeraya (siyasetçi, yönetici) daha rahat düşünme ve uygulama imkânı vermekte, onlara sorunların üstesinde gelmede tarihsel koşulların belirlediği toplumsal gerçeklik esas alınarak daha güzel teori ve doğru uygulamalar geliştirebilme yükümlülüğü vermektedir.

Hz. Peygamberin vefatından sonra İslam toplumunun siyasi ve dini olarak çözüm bulmak için ilk karşılaştığı mesele, hilafet meselesidir. ${ }^{36}$ Peygamber efendimizin vefatı üzerine Ensar, devlet başkanlığını kendi hakkı görmüştür. $\mathrm{Bu}$ nedenle Beni Saide Sakife'sinde toplanan Evs ve Hazreç kabilesi, önemli bir sahabi olan Hazreç kabilesine mensup Sa'd b. Ubade'ye devlet başkanı olarak biat ettiler. Bu olaydan haberdar olan Kureyşli Muhacir Hz. Ömer,

36 Hasan b. Musa en-Nevbahti, Fıraku'ş-Şiâ, thk. Helmut Ritter, (İstanbul:1931), 1-2. 
yanına Hz. Ebu Bekir'i de alarak oraya gitti. Orada devlet başkanl1ğının kimin hakkı olduğuna ve kimin daha ehil olduğuna ilişkin tartışma ve istişarelerden sonra, bu göreve en layık kişinin Hz. Ebu Bekir olduğuna karar verildi. ${ }^{37}$ Ancak Sa'd b. Ubade Hz. Ebu Bekir'e ve daha sonra halife olan Hz. Ömer'e de biat etmedi. İlk iki halife önemli bir siyasi rakip olan Sa'd'ın biatını alma yoluna gitmediler. Peygamber Efendimizin kızı Hz. Fatıma da Hz. Ebu Bekir'e biat etmemişti. Hz. Ali de Hz. Fatıma hayatta iken Hz. Ebu Bekir'e biat etmemişti. Hz. Ebu Bekir ve Ömer zamanında yapılmayan biatler, toplumsal bütünlügü bozucu siyasi ve fikri bir ayrışmaya dönüşmediğinden fiili bir muhalefet olarak değerlendirilemez. İslam toplumunun kuruluşunu gerçekleştirme aşamasında iken patlak veren ilk fiili muhalefetin başlangıcı Hz. Osman'ın devlet yönetimine ilişkin kararlarına karşı duyulan tepki ve bu tepki sonucu gelişen olumsuz atmosferin siyasi isyana kadar varmasiyla sonuçlanan gelişmedir. Ancak Hz. Osman'ın Ümeyyeoğullarına yönelik iltimasları ve atadığı valilerden duyulan memnuniyetsizlik ihtilafı derinleştirmiş ve muhalefeti fiili bir hale dönüştürmüştür. Bir grup Müslüman tarafından $\mathrm{Hz}$. Osman öldürülmüş, akabinde Medine ahalisi Hz. Ali'ye devlet başkanı olarak biat etmiştir. Bu olaylardan sonra İslam tarihinde siyasi talepler, çekişmeler, savaşlar ve ayrı̧̧malar hiç bitmemiştir. İktidar talebi olan muhalifler, bu amaçlarına ancak mevcut halifeyi devirmekle ulaşabilirlerdi. İktidar ile muhalefet arasında ayrılık Hz. Ali zamanında daha da derinleşmiştir. Cemel ve Sıffin savaşlarından sonra ortaya çıkan Hariciler, meşru Halife olan Hz. Ali'yi tekfir ederek onun siyasal meşruiyetinin olmadığını ilan ettiler. Allah için halifeye, hak ve adalet için idarenin (hükümet) yanlış ve yanlı tutumuna ve haksızlığına karşı muhalefet ettiler. ${ }^{38} \mathrm{~Hz}$. Ali bir taraftan kendi toplumundan ayrilan Hariciler diğer taraftan Hz. Osman'ın katillerini bahane ederek biat etmeyen Ümeyyeoğullarının muhalefeti ile uğraşmak zorunda kalmıştır. Hz. Ali'nin bir harici tarafından şehit edilmesinden sonra Ümeyyeoğulları iktidarı ele geçirmişlerdir. Bu süreçten sonra en kapsamlı muhalefet Ali oğulların ve yandaşlarının (Şia) yürüttükleri muhalefettir. Şiiler hilafetin Ali ve oğullarının hakkı olduğunu dillendirerek temel amaçlarının iktidarı ele geçirmek olduğunu deklare etmişler ve

37 İbnü'l-Esîr, Ebü'l-Hasen İzzeddîn, el-Kâmil fi't-Târîh, thk. M. Yusuf ed-Dekâke, (Beyrut: Dârü'l-Kütübil-İlmiyye, 2003), II/189-195.

38 Julius Welhausen, İslamiyet'in Illk Devirlerinde Dini-Siyasi Muhalefet, Çev.: Firkat Iş1ltan, (Ankara: 1996), 16. 
bunu gerçekleştirmek için ciddi mücadeleler vermişlerdir. İslam tarihinin en travmatik hadiselerinden biri olan Kerbela faciası ilk dönem İslam toplumunda ciddi rahatsızlıklar meydana getirmiştir. Bu rahatsızlığını fiili olarak göstermeyenler, onu vicdanlarında yaşattılar. Kerbela olayı ile Emevi Hanedanına karşı tenkit ve isyan (muhalefet) toplumsal tabanda daha da yaygınlaşmıştır. Kufe ve Basra merkezli birçok isyan yaşandı. Şiiler, Hariciler, Abbasiler, bazı komutan ve valiler Emevi yöneticilerine karşı birçok muhalif eyleme giriştiler. Emevilere karşı yapılan isyanlar, Ümeyyeoğullarının Arapçılığı yüzünden Mevalilerin yoğunlukta olduğu Irak ve İran havzasında çok fazla destek bulmuştur. ${ }^{39}$

Muaviye'nin, Hz. Ali ile savaşa çıkışını Allah'ın kaza ve kaderinin bir gereği olduğunu söylemesi ${ }^{40}$ toplumsal muhalefeti kırmanın ve azaltmanın yolu olarak gördüğünü söylemek mümkündür. Devletin yöneticileri, meşruiyetlerini dini bazı kavram ve referanslarla sağlamaya çalışarak toplumda muhalefetin filizlenmesini engellemek veya azaltmak için çaba sarf etmişlerdir. Emevilerin cebr anlayışı bu yaklaşımın bir sonucudur. Emevi ve Abbasi yöneticilerinin kendileri için Allah'a veya dine matuf sıfatlar kullanmaları da bu amacın bir gereğidir. Halifelerin kullandıkları "halifetullah fi'1ard" (Allah'ın yeryüzündeki temsilcisi), "eminullah" (Allah'ın güvendiği), "el-İmamu'l-mustafa (seçilmiş, seçkin önder) gibi sıfatlar, iktidarlarının teolojik olarak temellendirme çabalarıdır. Bu nitelendirmeler (sanlar), Emevi veya Abbasi yönetimini destekleyen hatipler, şairler ve kassas denilen vaizler tarafından kullanılarak yaygınlaştırılmıştır. ${ }^{41}$ İktidarı elinde bulunduranlar bu yolla kendilerine olan muhalefetin dinen doğru kabul edilemeyeceğine halkı ikna etme arayışında olmuşlardır. Sultanı/halifeyi Allah'ın yeryüzündeki halifesi ya da gölgesi olarak telakki etmek, muhalefete imkân tanımaz. Gölge aslın yansımasıdır. Asıl Allah olduğuna göre gölge de neredeyse o konumdadır. Bu durumda toplumsal tabandan iktidara yönelik bir muhalefet meşru olmaz.

İslam'da itikadi ekollerin din ile siyaset arasında kurdukları ilişki onların muhalefete imkân verme durumlarına ilişkin bir fikir

\footnotetext{
39 Ayrıntılı bilgi için bk. Marshall G. S. Hodgson, The Venture of Islam I, (Chicago: The University of Chicago Press, 1974), 241-255.

40 Muhammed Âbid el-Cabiri, İslam'da Siyasal Akıl, Çev.: Vecdi Akyüz, (İstanbul: Kitabevi Yay., 1997), 589.

41 Cabiri, İslam'da Siyasal Akıl, 592.
} 
vermektedir. Hz. Ali'nin taraftarı olan Şia, imameti sadece Ehl-i Beyt'in hakkı olarak değerlendirmiş ve erken tarihlerde olmasa da onu nübüvvetin devamı olarak telakki etmiştir. Hz. Peygamberin dindeki varisi konumundaki bu algı, muhalefete imkân tanımaz. Onlara göre muhalefet, Ali ve oğullarının hakkı gasp edildiği için yapılmalı, iktidarın tekrar onların eline geçmesi için her türlü mücadele verilmelidir. Bu nedenle Şia'nın çok farklı ekollere, anlayış ve mücadele yöntemlerine şahit olmaktayız. Hz. Ali'den sonra egemenliği ele geçiren Emevilere karşı iktidarın nas ve tayinle Ali ve oğullarının hakkı olduğunu savunan Şia ile iktidarın nesebe değil adalet sahibi bütün Müslümanların hakkı olduğunu savunan Hariciler, dini argümanlarla konuşan ilk kelami/siyasi ekoller olmuşlar. Emevilerin sürekli takibatına maruz kalan Ali oğulları (Şia) ve Hariciler, İslam siyaset tarihinde örgütlü muhalefetin ilk temsilcileri olmuşlar ve muhalefetlerini değişik şekillerde ortaya koymuşlardır. Bu hem fikirlerine hem de iktidarı ele geçirmek için mücadele anlayışlarına da yansımıştır. Müslüman toplumda muhalefetin gayri meşru kabul edilmesi, bunu yapanların toplum birlikteliğini, ümmet fikrini zedelediği suçlamalarına maruz kalması önemli bir problemdir. İktidarın varlığını sürdürmek adına uyguladığı baskı politikaları muhaliflerin şiddete eğilim göstermelerine götürmüştür. Şiddet, hem fikri hem de siyasi hareketi marjinalleştirir. Bu marjinalleşmenin ilk yaşandığı oluşumlar Şia ve Havaric'tir. Havaric "tekfir" ideolojisi ile marjinalleşirken, ${ }^{42}$ Şia'nın bazı grupları da Hz. Ali'nin imametini elinden alan ve kabul etmeyenleri tekfir ederek hatta bazı marjinal fırkalarında Ali'ye "ilahlık" ve "masumluk" iddiasında bulunarak- marjinalleşmişlerdir. ${ }^{43}$

İslam düşüncesi içerisinde iktidar meselesini nesebe, vasiyete, mirasa ait görmeler dışında, ümmete ait görenler de vardır. Emeviler ve Abbasiler hilafeti Kureyş'in tekelinde görmüşlerdir. Hariciler ise imameti soy, nesep ve vasiyete değil adalete ve yönetim becerisine bağlamakta ama icmayı şart görmektedir. Kaderi ve Mürci kabul edilen Gaylan ed-Dımeşki ise iktidar meselesini tüm ümmete ait bir mesele olarak görmektedir. ${ }^{44}$ Mutezile ekolü de imameti halka ait bir mesele olarak görmekte, devlet başkanının adil ve yönetim

42 Nevbahtî, Frraku'ş-Şı̂â, 6, 14.

43 Nevbahtî, Frraku'ş-Şî̂, 19-24; Ebi'l-Hüseyin M. b. Ahmed Abdurrahman eş-Şafî Malati, et-Tenbih ve'r-Reddi Âla Ehva-î Bid'â, (Beyrut: Mektebet'i-Maârif, 1968), 156-158; Mustafa, İslam Düşüncesinde Muhalefet, 31.

44 Cabiri, İslam'da Siyasal Akll, 614. 
becerisi yüksek Müslümanlardan olması gerektiğine vurgu yapmaktadır. Şayet devlet başkanı adaletten saparsa, ehliyetini kaybederse şartlar oluştuğunda devlet başkanını değiştirmek gerekir. Hilafeti, Kureyş'e öncelik vermekle birlikte ehil tüm Müslümanların bir hakkı gören Ehl-i Sünnet Şia'daki kadar olmasa da, siyasal otoriteye dini bir zemin vermektedir. Ehl-i sünnet ekolü "Ey iman edenler! Allah'a itaat edin, elçisine itaat edin ve sizden olan yetki sahiplerine de itaat edin" 45 ayetini referans kabul ederek yöneticiyi itaat etmeyi bir gereklilik ve zorunluluk kabul etmişlerdir. Hasan Hanefi, Müslüman geleneğindeki otoriteryen anlayışla Eş'arilerin, dilediği gibi tasarrufta bulunan Kadir-i Mutlak tanrı inancı arasında bir ilişki kurar. ${ }^{46}$ Bununla birlikte genel olarak şu söylenebilir. Hariciler, Mutezile ve Ehl-i Sünnet (Şiiler istisna, onlara göre nass ve tayinle olur) devlet başkanlığı meselesini ümmete ait bir mesele olarak telakki etmektedir. Müslümanların düşünce geleneğinde üretilen teorilerdeki esneklik, var olan siyasi gerçekliğe yansımamıştır. Nesebe dayanan saltanat geleneği siyaset kurumunun bu teorilere göre şekillenmesine imkân vermemiştir. Dolayısıyla muhalefette siyaset kurumu içerisinde kurumsal olarak yer bulmamıştır. Ancak bir kısım Müslüman âlimler, dini bir sorumluluk gereği devlet yöneticilerine yönelik uyarı ve eleştirilerde bulunmuşlardır. Bu örgütlü bir faaliyetten ziyade dini ve vicdani bireysel bir tepkidir. Bir kısım düşünürler devlet yöneticilerine kılavuzluk yapacak nitelikte eserler telif etmişlerdir.

İslam düşünce tarihinde ana hatlarıyla iktidara yönelik üç tür siyasi tavrın ortaya konulduğu görülmektedir: Bu üç tavırdan birincisi Haricilerin tutumudur. Fırsat ve imkân bulduklarında, güç yetirebilirlerse ayaklanıp iktidarı devirip ehil birisine teslim etme yaklaşımıdır. Bu tutum devrimci (sevra) tavırdır. İkincisi Mürcie'nin yaklaşımını benimseyen Ehl-i Sünnet' in tutumudur. Bu yaklaşımı benimseyenler, iktidarın varlığına ve uygulamalarına karşı sabırlı olmayı telkin edip toplumun siyasi ve dini birliğinin korunması gerektiğine vurgu yapmışlardır. Üçüncü tavır olan temekkün ise devrim ile sabır ekolu arası bir yer tutarak şartlar oluştuğunda ve güç yetirebildiğinde devrim de dâhil her türlü muhalefet örneği

\footnotetext{
Nisa, 59.

46 Recep Ardoğan, “Teorik Temeller ve Tarihsel Gerilimler Arasında İslam Kültüründe Siyasal Muhalefet", Cumhuriyet Üniversitesi Illahiyat Fakültesi Dergisi, C. VIII/2, 2004, s. 177.
} 
verilebilir. Bu son tavır alma şekline Mutezile'nin yaklaşımı örnek verilebilir. $^{47}$

İlk dört halifeden hiçbirisi bir önceki devlet başkanının seçildiği gibi seçilmemiş ve göreve başlamamıştır. İlk dört halife sırasıyla İstişare, tavsiye/telkin, komisyon/şûra ve Medine ahalisinin genel biatı ile devlet başkanı olmuşlardır. Devlet modeli, yönetici seçimi ve denetim sistemi gibi önemli konularda, Kur'an ve Sünnet'in herhangi bir belirlenimde bulunmaması, bu konuların içtihadi bir alan olduğunu ortaya koymakta ve sorumluluğu Müslümanların omuzlarına yüklemektedir. Müslüman âlim ve siyasetçiler, teorik ve pratik açından adil bir yönetim belirlemeyi, hak ve hukuka uygun bir mekanizma oluşturmayı, uygulamaların hak ve adalet üzere olduğunu denetleyecek bir sistem kurmayı esas almalıdırlar. Bunu yaparken toplumsal yapı ve ihtiyaçlar dikkate alarak siyasete yönelik tartışmaları aktif tutmalıdırlar ki doğrunun arayışı ve uygulamaların denetimi sağlansın.

İslam siyaset tarihinin hiçbir döneminde kurumsal mekanizmaya dönüşen bir muhalefet olmamıştır. Bu devletlerin yönetim biçimlerinin imamet, hilafet, saltanat yapısından kaynaklanan bir durumdur. Bu yönetimler, otoriter bir nitelik taşıdıklarından dolayı, danışma/istişare meclisi özelliklerini taşısalar da genel olarak tek sesliliğin egemen olduğu bir çizgide siyaset üretmişlerdir. İktidarın yönetiminden memnun olmayanların veya iktidara talip olanların önünde isyan etmekten başka seçenek kalmamıştır. Bu nedenle İslam tarihinde birçok isyan yaşanmıştır. İktidardan rahatsız olanların örgütlü olarak devlet yöneticilerinin politikalarını benimsemeyen ve yerine alternatif bir yönetim öngörenlerin başvuracakları tek yol, mevcut iktidarın meşruiyet problemi taşıdığını ve onun devrilmesini talep etmekti. Bunun tek yolu da isyanlarla mevcut siyasal otoriteyi zayıflatıp devirmektir. Ancak son iki asırda Batıda yaşanan siyasi, sosyal ve ekonomik değişiklikler, tüm dünyanın siyaset mekanizmalarını derinden etkilemiş, devletler ve milletler bazı yeni arayışlara zorunlu olarak girişmişlerdir. Bu süreçte muhalefet, yasal bir zemine dayanarak var olan iktidara alternatif bir iktidar seçeneği olarak benimsenmiştir. Bu fikir krallık, saltanat ve

47 Bu konuda detaylı bilgi için bk. Mustafa, İslam Düşüncesinde Muhalefet, s. 33. 
dini otoritelere dayanan geleneksel yönetim sistemlerinin yerine çoğulcu ve katılımcı yönetim biçimlerinin tercih edilmesine yol açmıştir.

\section{Sonuç}

İslam'ın muhalefet olgusuna bakışı, muhalefetin kime, niçin ve nasıl yapıldığına bağlı olarak zorunlu, gerekli, yanlış şeklinde bir değerlendirmeye tâbi tutulabilir. Muhalefet, siyasal ve toplumsal bütünlüğü zedeleyici, düzeni ifsat edici bir amaç ve çaba ile yapılıyorsa İslam'ın bunun olumlu görmesi beklenemez. Ama muhalefet dinin makâsıdını gerçekleştirmek, egemen anlayış veya iktidarın görüş ve politikalarından daha doğru alternatif bir görüş ve politika üretmek, onlara denetim sağlamak, yanlışı düzeltmek, zulmü engellemek ve benzeri gayelerle yapılırsa pozitif anlam yüklü bir kavram haline dönüşür. Devlet, toplumun kurumsal işlerini sevk ve idare eden en büyük aygıt olduğuna göre bunun doğru ve adil bir siyaset modeli üzere işlemesi bir gereklilik arz etmektedir. Günümüz dünyasında böyle bir modelin olması için iktidar kadar muhalefet de gereklidir.

İslam düşünce ve siyasi tarihi esas alındığında, muhalefetin fikri ve siyasi yönünün bulunduğu görülmektedir. Müslüman düşünürlerin kelam, felsefe, tasavvuf, fıkıh ve tefsir gibi İslami ilimlerde ürettikleri düşüncenin çeşitliliği, fikri muhalefetin teorik bir zenginlik olarak benimsendiğini göstermektedir. İslam tarihinde uzunca bir süre düşüncenin dinamik bir şekilde varlığını sürdürmesinde Müslüman düşünürler arasında yaşanan ihtilaflar üzerinde gerçekleşen münâzara, mu'âraza, cedel ve reddiyelerin önemli bir etkisi vardır. İslam siyasi tarihinde ise muhalefetin, yönetim sistemlerinin imkân vermemesinden kaynaklanan bir meşruiyet krizi yaşadığ1 söylenebilir. İslam siyaset tarihindeki imamet, hilafet, saltanat modelleri, meşruiyetlerini dini zeminde aradıkları için zamanla bu yönetim modelleri dini bir kimlik kazanmıştır. Siyaset modellerinin dini zeminde kendilerine yer bulma çabaları, yöneticilerin kendilerine olan muhalefeti en aza indirgeme ve otoritelerine meşruiyet kazandırma düşüncesinden hareketle ortaya konulmuştur. Dini bir kisve biçilmiş yönetim modeli, toplum nezdinde kendilerine yapılacak eleştiriyi minimize edecektir. Şu bir gerçektir ki tek elden yönetimlerde muhalefet çoğu zaman bağilik, asilik, ihanet ile nitelendirilmiş ve dönemin siyasi erkleri tarafından ötekileştirilerek marjinalize ya da terörize edilmiştir. İslam siyaset tarihinde de durum bundan pek farklı olmamıştır. İktidarı elinde bulunduran güç, 
siyasal otoritesinin meşruiyetine ilişkin tartışmaları kabul etmemiş, bu eleştiriyi yapanları asi ve baği olarak niteleyerek güç kullanmış, siyasal bir alternatif olmasını engellemeye çalışmıştır.

\section{Kaynakça}

Alevâni, Cabir. İslâm'da İhtilâf Usûlü. Terc.: Abdulhalim Ural, İstanbul: Risale, 1991.

Ardoğan, Recep. “Teorik Temeller ve Tarihsel Gerilimler Arasında İslam Kültüründe Siyasal Muhalefet", Cumhuriyet Üniversitesi Illahiyat Fakültesi Dergisi, C. VIII/2, 2004, s. 171-189.

Başoğlu, Tuncay. “Tefrika”, DIA., XL, İstanbul 2011.

Cabiri, Muhammed Âbid. İslam'da Siyasal Akıl. Çev. Vecdi Akyüz. İstanbul: Kitabevi Yayınları, 1997.

Cürcânî, Seyyid Şerîf. et-Ta'rifat. thk. Nasruddin Tunusi. Kahire: 2007.

Eş'arî, Ebu'l- Hasan. Makalâtü'l-İslâmiyyîn ve ihtilafu'l-musallîn. Nşr. Helmut Ritter. Wiesbaden: 1980.

Hodgson, Marshall G. S. The Venture of Islam I. Chicago: The University of Chicago Press, 1974.

İbnü'l-Esîr, Ebü'l-Hasen İzzeddîn. el-Kâmil fi't-Târîh. thk.: M. Yusuf edDekâke. Beyrut: Dârü'l-Kütübil-İlmiyye, 2003.

İbn Manzur. Lisanü'l-Arab. Beyrut: Daru'l-İhya Turasi'l-Arab, 3. Baskı, trs.

İbn Seyyid el-Batlayusi. el-İnsaf. thk.: Muhammed Ridvan Daye. Suriye: Daru'l-Fikr, 2003.

İsfahânî, Râgıp. el-Müfredatu elfazi'l-Kur'an. thk. Safvan Adnan Davudi. D1meşk: Daru'l-Kalem, 2009.

İzmirli İsmail Hakkı. İlm-i Hilaf. İstanbul: Dar Saadet, 1330.

Kardavî, Yusuf. İhtilâflar Karşısında İslamî Tavır. Çev.: Osman Arpaçukuru. İstanbul: İlke Yayıncılık, 2. Baskı, 1996.

Koçyiğit, Talat. Hadisçiler ile Kelamcılar Arasındaki Münakaşalar. Ankara: AÜİF. Yayınları, 1969.

Malâti, Ebü'l-Hüseyin. et-Tenbih ve'r-Reddi Âla Ehvâ̂ Bid'â. Mektebet'iMaârif, Beyrut 1968.

Mustafa, Nevin Abdulhâlık. İslam Düşüncesinde Muhalefet. Çev.: Vecdi Akyüz. İstanbul: İz Yayınları, 2001.

Nevbahti, Hasan b. Musa. Fıraku'ş-Şiâ. thk.: Helmut Ritter. İstanbul: 1931.

Öge, Sinan. "Usûlu'd-Dinde İhtilafın Hükmü ve Eleştirisi”. Ekev Dergisi. 11/33, Güz 2007, ss.107-120.

Özen, Şükrü. "İhtilaf" md., DİA. XXI, İstanbul 2000.

Süt, Abdulnasır. Basra ve Mutezile. Ankara: İlahiyat Yayınları, 2016.

Şafak, Ali. "Bağy”, DİA, IV, İstanbul: 1991.

Şehristani, Ebi Feth M.b. Abdulkerim b. Ebi Bekr Ahmed. el-Milel ve'n-Nihal. I-II, thk.: Emir Ali Mehna, Ali Hasan Faur. Beyrut: Daru'l-Marife, 2001. 
İslam Düşüncesinde Muhalefet

Wellhausen, Julius. İslamiyet'in İlk Devrinde Dini-Siyasi Muhalefet. Çev.: Fikret Işıltan. Ankara: Türk Tarih Kurumu Yayınları, 1996.

Yazıcıoğlu, Mustafa Sait. İslam Düşüncesinin Tarihsel Gelişimi. Ankara: Akçă̆ Yayınları, 2001. 